\title{
Socio Economic Characteristics of Buffalo Farmers in Haryana
}

\author{
Kamal Kumar ${ }^{1 *}$, Mahesh Chander ${ }^{1}$, Lalita Garg ${ }^{2}$ and Rishi Kumar Singh ${ }^{3}$ \\ ${ }^{1}$ Division of Extension Education, ${ }^{2}$ Division of Livestock Products Technology, Indian \\ Veterinary Research Institute, Izatnagar, Bareilly (Uttar Pradesh), India \\ ${ }^{3}$ Department of Agricultural Extension, ANDUAT, Kumarganj, \\ Ayodhaya (Uttar Pradesh), India \\ *Corresponding author
}

A B S T R A C T

Keywords

Buffalo farmers, Haryana, Socioeconomic profile, Age group, Income, Caste, Family

Article Info

Accepted:

17 January 2021

Available Online:

10 February 2021
The present study was conducted in randomly selected Karnal, Kurukshetra and Hisar districts of Haryana. A total of 120 buffalo farmers form part of the study. An ex post facto research design was used for the study. It was found that $68.30,16.70$ and 15.00 per cent respondents belonged to middle, old and young age group, respectively. An overwhelming majority $(93.30 \%)$ of the respondents who practiced buffalo farming were male, followed by only 6.70 per cent females. More than half $(60.80 \%)$ of the buffalo farmers were from general caste followed by 32.50 and 6.70 per cent from backward caste and schedule caste, respectively. Around half $(51.70 \%)$ of the respondents' belonged to joint families followed by 48.30 per cent nuclear families. A majority $(76.70 \%)$ of the respondents were having small size herds followed by 20.00 per cent medium and only 3.30 per cent possessed large size herds. It was found that $60.80,34.20$ and 5.00 per cent farmers belonged to low, medium and high income groups.

\section{Introduction}

India is the leading milk producer nation in the world contributing 18.60 per cent in the total milk production of the world. The livestock sector is contributing 4.50 per cent in the total Gross Value Added and 25.80 per cent in the agricultural Gross Value Added at current basic prices (GOI, 2017 ${ }^{\mathrm{a}}$ ). The improvement of dairy production will be particularly important in the coming years, as the demand for livestock products is expected to double by 2020 (Rangnekar, 2006).
Buffalo husbandry in the Indian context is very intimately interwoven with the country's rural economy that its prevalence as a source of food and additional income transcends all socio-economic boundaries of rural life. This is a blessed heritage of people of India which needs to be resurrected through applied innovations and cooperative human resource utilization.

In India, most of the population depends on agriculture and livestock production which are linked to each other in various aspects. In 
turn, the majority of them depend on the livestock sector directly or indirectly for their subsistence. This sector is providing employment to 8.80 per cent of the population and livelihood to 20.6 million people. The country has around 2.29 per cent land area of the world and sustaining 11.60 per cent of the world livestock population. India possesses the largest animal husbandry sector of the world with around 512.06 million livestock heads (GOI, 2017 ${ }^{\mathrm{b}}$ ).

\section{Materials and Methods}

The present study was conducted in three districts of Haryana i.e. Karnal, Kurukshetra and Hisar. Four villages from each district to a total of twelve villages constituted the study area. From each selected village, a sampling frame having the list of buffalo farmers possessing at least one adult female buffalo was prepared with the help of the veterinary surgeons. Ten buffalo farmers were selected randomly, from the list, to arrive at a total sample size of 120 farmers. An ex-post facto research design was used in the study.

\section{Results and Discussion}

\section{Age}

A perusal of Table 1 indicates that the average age of the buffalo farmers was 47.74 years, while a majority $(68.30 \%)$ of the respondents belonged to middle age (38-56) years. Only 15.00 per cent of respondents were in young age (19-37) years group, whereas 16.70 per cent were in the old age group (57-75) years. The results were in line with the findings of Rachna et al., (2017) who conducted study on socioeconomic profile of dairy farmers in Haryana, and observed that majority $(73.30 \%)$ of the respondents were in middle age group followed by 15.00 per cent and 11.70 per cent in each old and young age group, respectively with a mean age of about 43 years.

\section{Sex}

It is evident from Table 2 that an overwhelming majority $(93.30 \%)$ of the respondents selected for the study practiced buffalo farming were male and only 6.70 per cent of respondents were females.

\section{Caste}

As shown in Table 3 most of the buffalo farmers $(60.80 \%)$ were from general caste followed by 32.50 per cent other backward castes and the remaining 6.70 per cent belonged to schedule caste. The observations were in accordance with Sarita (2017) and Yadav (2018) who in their study on dairy farmers of Haryana found that majority of the respondents 50.00 per cent and 75.80 per cent respectively represented the general category.

\section{Family type}

As indicated in Table 4 that 51.70 per cent of the respondents' belonged to joint families while remaining 48.30 per cent represented nuclear families. Similar findings were reported by Rachna et al.(2017) who studied the socio-economic profile of dairy farmers in Haryana and found that majority $(65.00 \%)$ of the dairy farmers' belonged to joint families.

\section{Family size}

As far as Table 5 is concerned 50.00 per cent of the farmers had a small family size (1-5 members) followed by 36.70 per cent (6-10 members) medium family size and only 13.30 per cent had large sized (11-15 members) families. The observation was in line with the findings of Yadav (2018) who studied the effectiveness of breeding services of animal husbandry department in Haryana and found that majority $(73.30 \%)$ of the respondents had small size families (up to 7 members). 
Table.1 Distribution of respondents according to their age

\begin{tabular}{|c|c|cc|}
\hline Age (in years) & Frequency $(\mathbf{n = 1 2 0})$ & & \\
\hline Young $(\mathbf{1 9 - 3 7})$ & $18(15.00)$ & Mean $=\mathbf{4 7 . 7}$ & SE \\
Middle (38-56) & $82(68.30)$ & $\mathbf{0 . 9 0 1}$ & \\
\hline Old (57-75) & $20(16.70)$ & & \\
\hline
\end{tabular}

Figures in parenthesis indicate percentage, SE- standard error

Table.2 Distribution of respondents according to their sex

Figures in parenthesis indicate percentage

\begin{tabular}{|c|c|}
\hline Sex & Frequency $(\mathbf{n}=\mathbf{1 2 0})$ \\
\hline Male & $112(93.30)$ \\
\hline Female & $8(6.70)$ \\
\hline
\end{tabular}

Table.3 Distribution of respondents according to their caste

\begin{tabular}{|c|c|}
\hline Caste & Frequency $(\mathbf{n}=\mathbf{1 2 0})$ \\
\hline General & $73(60.80)$ \\
\hline OBC & $39(32.50)$ \\
\hline SC & $8(6.70)$ \\
\hline
\end{tabular}

Figures in parenthesis indicate percentage

Table.4 Distribution of respondents according to their type of family

\begin{tabular}{|c|c|}
\hline Type of family & Frequency $(\mathbf{n}=\mathbf{1 2 0})$ \\
\hline Nuclear & $58(48.30)$ \\
\hline Joint & $62(51.70)$ \\
\hline
\end{tabular}

Figures in parenthesis indicate percentage

Table.5 Distribution of respondents according to their family size

\begin{tabular}{|c|c|c|}
\hline Family size & Frequency $(\mathbf{n}=\mathbf{1 2 0})$ & \\
\hline Small (1-5) & $60(50.00)$ & Mean $=\mathbf{6 . 4 5}$ \\
\cline { 1 - 2 } Medium (6-10) & $44(36.70)$ & $\mathbf{S}=\mathbf{0 . 2 6 7}$ \\
\hline Large (11-15) & $16(13.30)$ & \\
\hline
\end{tabular}

Figures in parenthesis indicate percentage, SE- standard error

Table.6 Distribution of respondents according to their education

\begin{tabular}{|c|c|}
\hline Education & Frequency $(\mathbf{n}=\mathbf{1 2 0})$ \\
\hline Illiterate & $8(6.70)$ \\
\hline Primary school & $13(10.80)$ \\
\hline Middle school & $11(9.20)$ \\
\hline High school & $40(33.30)$ \\
\hline Secondary school & $31(25.80)$ \\
\hline Graduation and above & $17(14.20)$ \\
\hline
\end{tabular}

Figures in parenthesis indicate percentage 
Table.7 Distribution of respondents according to their primary occupation

\begin{tabular}{|c|c|}
\hline Primary Occupation & Frequency $(\mathbf{n = 1 2 0})$ \\
\hline Agriculture & $70(58.30)$ \\
\hline Livestock & $25(20.80)$ \\
\hline Labour & $1(0.80)$ \\
\hline Others & $24(20.00)$ \\
\hline
\end{tabular}

Figures in parenthesis indicate percentage

Table.8 Distribution of respondents according to their secondary occupation

\begin{tabular}{|c|c|}
\hline Secondary occupation & Frequency $(\mathbf{n}=120)$ \\
\hline Agriculture & $16(13.30)$ \\
\hline Livestock & $91(75.80)$ \\
\hline Labour & $10(8.30)$ \\
\hline Others & $3(2.50)$ \\
\hline
\end{tabular}

Figures in parenthesis indicate percentage

Table.9 Distribution of respondents according to their experience in buffalo rearing

\begin{tabular}{|c|c|c|}
\hline Experience in buffalo rearing (in years) & Frequency $(\mathbf{n}=\mathbf{1 2 0})$ & \\
\cline { 1 - 2 } Low (0-9) & $1(0.80)$ & Mean $=\mathbf{2 8 . 4 7}$ \\
\cline { 1 - 2 } Medium (10-31) & $79(65.90)$ & SE $=\mathbf{0 . 8 1 8}$ \\
\hline High (>31) & $40(33.30)$ & \\
\hline
\end{tabular}

Figures in parenthesis indicate percentage, SE- standard error

Table.10 Distribution of respondents according to their landholding size

\begin{tabular}{|c|c|}
\hline Land holding & Frequency $(\mathbf{n}=\mathbf{1 2 0})$ \\
\hline Landless & $26(21.70)$ \\
\hline Marginal farmer $(<\mathbf{1}$ ha) & $18(15.00)$ \\
\hline Small farmer $(\mathbf{1 - 2}$ ha) & $29(24.20)$ \\
\hline Semi-medium farmer $(\mathbf{2}-\mathbf{4}$ ha) & $5(4.20)$ \\
\hline Medium farmer (4-10 ha) & $29(24.20)$ \\
\hline Large farmer $(>\mathbf{1 0}$ ha) & $13(10.80)$ \\
\hline
\end{tabular}

Figures in parenthesis indicate percentage

Table.11 Distribution of respondents according to their herd size

\begin{tabular}{|c|c|}
\hline Herd size & Frequency $(\mathbf{n}=\mathbf{1 2 0})$ \\
\hline Small (1-5) & $92(76.70)$ \\
\hline Medium (6-10) & $24(20.00)$ \\
\hline Large (11-15) & $4(3.30)$ \\
\hline Mean = 3.62 & SE $=\mathbf{0 . 2 2 9}$ \\
\hline
\end{tabular}

Figures in parenthesis indicate percentage, SE- standard error 
Table.12 Distribution of respondents according to their gross annual income

\begin{tabular}{|c|c|}
\hline Total income & Frequency $(n=120)$ \\
\hline Low $(50,000-7,00,000)$ & $73(60.80)$ \\
\hline Medium $(7,00,001-14,00,000)$ & $41(34.20)$ \\
\hline High $(14,00,001-21,00,000)$ & $6(5.00)$ \\
\hline \multicolumn{2}{|l|}{ Mean $=$ Rs. 6,06,768 } \\
\hline Agricultural gross annual income & Frequency $(n=120)$ \\
\hline Low $(0-60,00,00)$ & $91(75.80)$ \\
\hline Medium $(6,00,001-12,00,000)$ & $19(15.80)$ \\
\hline High $(12,00,001-18,00,000)$ & $10(8.40)$ \\
\hline \multicolumn{2}{|l|}{ Mean = Rs. 3,52,166.66 } \\
\hline Livestock gross annual income & Frequency $(n=120)$ \\
\hline Low $(20,000-2,20,000)$ & $109(90.80)$ \\
\hline Medium $(2,20,001-4,20,000)$ & $10(8.40)$ \\
\hline High $(420,001-6,20,000)$ & $1(0.80)$ \\
\hline \multicolumn{2}{|l|}{ Mean $=$ Rs. $1,23,235$} \\
\hline Nonagricultural gross annual income & Frequency $(n=120)$ \\
\hline Low $(0-4,00,000)$ & $105(87.50)$ \\
\hline Medium(4,00,001-8,00,000) & $5(4.20)$ \\
\hline High $(8,00,001-12,00,000)$ & $10(8.30)$ \\
\hline Mean = Rs. 1,31,366 & \\
\hline
\end{tabular}

Figures in parenthesis indicate percentage

Table.13 Distribution of respondents according to their mass media exposure

\begin{tabular}{|c|c|}
\hline Mass media exposure & Frequency $(\mathbf{n}=\mathbf{1 2 0})$ \\
\hline Low & $18(15.00)$ \\
\hline Medium & $52(43.30)$ \\
\hline High & $50(41.70)$ \\
\hline Mean $=\mathbf{1 9 . 4 1}$ & SE $=\mathbf{0 . 0 6 5}$ \\
\hline
\end{tabular}

Figures in parenthesis indicate percentage, SE- standard error

Table.14 Distribution of respondents according to their localite extension agency contact

\begin{tabular}{|c|c|}
\hline Extension agency contact localite & Frequency $(\mathbf{n = 1 2 0})$ \\
\hline Low & $8(6.60)$ \\
\hline Medium & $54(44.60)$ \\
\hline High & $59(48.80)$ \\
\hline Mean $=\mathbf{1 0 . 9 6}$ & SE $=\mathbf{0 . 0 5 6}$ \\
\hline
\end{tabular}

Figures in parenthesis indicate percentage, SE- standard error 
Table.15 Distribution of respondents according to their cosmopolite extension agency contact

\begin{tabular}{|c|c|}
\hline Extension agency contact cosmopolite & Frequency $(\mathbf{n}=\mathbf{1 2 0})$ \\
\hline Low & $53(44.20)$ \\
\hline Medium & $28(23.30)$ \\
\hline High & $39(32.50)$ \\
\hline Mean $=\mathbf{1 6 . 2 2}$ & SE $=\mathbf{0 . 0 8 0}$ \\
\hline
\end{tabular}

Figures in parenthesis indicate percentage, SE- standard error

Table.16 Distribution of respondents according to their level of social participation

\begin{tabular}{|c|c|}
\hline Social participation & Frequency $(\mathbf{n}=\mathbf{1 2 0}$ \\
\hline Low & $95(79.20)$ \\
\hline Medium & $8(6.70)$ \\
\hline High & $17(14.20)$ \\
\hline Mean total score $=\mathbf{2 . 5 3}$ & $\mathbf{S E}=\mathbf{0 . 0 6 4}$ \\
\hline
\end{tabular}

Figures in parenthesis indicate percentage, SE- standard error

\section{Education}

As Table 6 indicates 33.30 per cent of the buffalo farmers possessed high school education, followed by 25.80 per cent secondary school, while 14.20 per cents were graduates and above. It was found that 10.80 per cent and 9.20 per cent were studied upto primary school and middle school respectively, whereas 6.70 per cent were illiterate.

The observations were in concurrence with the finding of Ahuja (2015) who conducted a study on entrepreneurial behavior of dairy farmers in Haryana and revealed that majority of the respondents had more than the high school of education.

\section{Occupation}

As for as occupation was concerned more than half $(58.30 \%)$ of the respondents had agriculture as primary occupation (Table 7) and two third $(75.80 \%)$ of the respondents had livestock as a secondary occupation (Table 8).

\section{Experience in buffalo rearing}

With regard to buffalo rearing experience, it was found that around two third $(65.90 \%)$ of the buffalo farmers were classified as medium, having 10-31 years of buffalo rearing experience, followed by 33.30 per cent as high $>31$ years and only 0.80 per cent as low 0-9 years of buffalo rearing experience (Table 9).

The observations were in accordance with the finding of Ahuja (2015) who conducted a study on entrepreneurial behavior of dairy farmers in Haryana and revealed similar findings with regard to dairy experience.

\section{Landholding size}

With regard to landholding size it was found that $24.20,24.20,21.70,15.00,10.80$ and 4.20 per cent farmers were small, medium, landless, marginal, large and semi-medium farmers, respectively. The findings were in concurrence with Sarita (2017) who conducted a study on problems and prospects of buffalo husbandry in Haryana and revealed 
that majority of the respondents were small farmers with land holding (upto 2 ha) (Table 10).

\section{Herd size}

As shown in Table 11, majority $(76.70 \%)$ of the respondents had small sized herds followed by 20 per cent who had medium size herds and only 3.30 per cent respondents had large herds. The observation were in line with Yadav (2018) who studied the effectiveness of breeding services of animal husbandry department in Haryana and found that majority $(71.70 \%)$ of the respondents had small size of livestock holdings.

\section{Gross annual income}

As evident from Table 12, average total gross annual income of the buffalo farmers was Rs. $6,06,768$. More than half $(60.80 \%)$ of the buffalo farmers were having low (Rs. 50,000$7,00,000)$ total gross annual income, followed by 34.20 per cent in medium income group (Rs. 7,00,001-14, 00,000) and only 5.00 per cent farmers selected for the study were placed in high income group (Rs. 14,00,00121,00,000).

The observation were in accordance with the finding of Yadav (2018) who studied the effectiveness of breeding services of animal husbandry department in Haryana and observed that majority of the buffalo farmers $(67.00 \%$ ) belonged to low gross annual income category and could earn < Rs. 4,00,000 per annum.

\section{Mass media exposure}

As reflected in Table 13 it was found that a sizeable population of the buffalo farmers $(43.30 \%)$ had medium level of mass media exposure followed by 41.70 per cent who had high level of mass media exposure and remaining 15.00 per cent had low mass media exposure. Similar results were reported by Yadav (2018) who studied the effectiveness of breeding services of department of animal husbandry in Haryana and found that majority of the buffalo farmers fell in medium category in utilizing mass media sources.

\section{Extension agency contact}

As indicated in Table 14 about half $(48.80 \%)$ of the buffalo farmers had high level of personal localite extension agency contact, while 44.60 per cent had medium level of personal localite extension agency contact and only 6.60 per cent buffalo farmers were having low level of personal localite extension agency contact.

It is apparent from Table 15 that 44.20 per cent of the buffalo farmers had low cosmopolite extension agency contact, followed by 32.50 respondents having high level of cosmopolite extension agency contact and rest of 23.30 per cent had medium level of cosmopolite extension agency contact. Similar findings were observed by Ahuja (2015) and Rachna et al., (2017) while studying dairy farmers of Haryana.

\section{Social participation}

As shown in Table 16, majority (79.20\%) of the respondents had low level of social participation, followed by 14.20 per cent respondents were having high level of social participation and remaining 6.70 per cent respondents had medium level of social participation.

The findings were in concurrence with the observation of Ahuja (2015) and Rachna et $a l$. , (2017) who did study on dairy farmers in Haryana and found that majority of the dairy farmers had low social participation. 


\section{References}

Ahuja, R. 2015. Entrepreneurial behavior of buffalo dairy farmers in Haryana. M.V.Sc. Thesis, Lala Lajpat Rai University of Veterinary and Animal Sciences, Hisar, Haryana, India. Accessed throughhttp://krishikosh.egranth.ac.in/h andle/1/5810026934 on 26.08.2018.

Government of India. 2017a. Basic Animal Husbandry and Fisheries Statistics. Ministry of Agriculture and Farmers Welfare, Department of Animal Husbandry, Dairying and Fisheries, Krishi Bhawan, New Delhi. Accessed throughhttp://dahd.nic.in/sites/default/fil ess/BasicAnimal Husbandry and Fisheries Statistics 2017 (English version)_5.pdf on 05.09.2018.

Government of India. 2017b. 19th Livestock Census 2012, Ministry of Agriculture and Farmers Welfare, Department of Animal Husbandry, Dairying and Fisheries, Krishi Bhawan, New Delhi Accessed through http://dahd.nic.in /sites/default/filess/

Livestock\%20\%205_0.pdf on 05.09.2018.

Rangnekar, D.V. 2006. Livestock and livelihood of the underprivileged communities in India: A review. International Livestock Research Institute, Nairobi, Kenya.72.

Rachna, Gautam,Malik, A., Sangwan, S.S., Khirbat, R. and Kamaldeep. 2017. Socioeconomic profile of dairy farmers in Hisar district of Haryana. The Asian Journal of Animal Science, 12(1): 8894.

Sarita. 2017. Problems and prospects of Buffalo Husbandry in Haryana. Ph.D. Thesis, Lala Lajpat Rai University of Veterinary and Animal Sciences, Hisar (Haryana), India. Accessed through http://krishikosh.egranth.ac.in/handle/1/ 581037373 on 02.08 .2018

Yadav, R. 2018. Effectiveness of breeding services of animal husbandry department of Haryana. Ph.D. Thesis, IVRI, Izatnagar, Uttar Pradesh, India.

\section{How to cite this article:}

Kamal Kumar, Mahesh Chander, Lalita Garg and Rishi Kumar Singh. 2021. Socio Economic Characteristics of Buffalo Farmers in Haryana. Int.J.Curr.Microbiol.App.Sci. 10(02): 22022209. doi: https://doi.org/10.20546/ijcmas.2021.1002.262 